\title{
Valuing Biodiversity: A Qur'anic Account
}

\author{
A. K. H. Solihu
}

\begin{abstract}
Species diversity has been the hallmark of biosphere and invaluable resource for human being as well as for the natural environment. In order to appreciate and conserve these diverse species which are constituents of nature, different values from different frames of references have been proffered. This study examines biological diversity from the Qur'anic perspective in an attempt to explicate the kinds of value conferred by the Qur'an on non-human species, particularly among the animals and plants. Collating ayat (verses) of the Qur'an related to nonhuman species and analyzing key conceptual terms the Qur'an employs in reference to their diversity, the study found that nonhuman species are presented in the Qur'an as signs of God and as communities of worshipers worthy of existence and conservation.
\end{abstract}

Index Terms-Environmental ethics, biodiversity conservation, nonhuman animals, Qur'anic ecology.

\section{INTRODUCTION}

The Qur'anic account and recognition of diversity in nature could be traced back to the moment when Prophet Adam was taught al-asma' kullaha, the names of things or the capacity to name things (Qur'an, 2:31-32). This suggests that there are, at least, several things out there which he could identify but which the angels could not. Biological items from which he was created, namely, water and dust, could be among the items of identification. Next, he was placed in the Jannah (garden) together with Eve where they were at liberty (raghadan) to eat and drink from all types of fruits and to take shelter and cloth therein, with the exception of a particular tree forbidden for them (Qur'an, 2:35; 7:19; 20:118-119). In this earliest encounter between human and nature, as recorded in the Qur'an, a variety of biological things are purposefully placed in Jannah that will make it habitable for Adam and Eve, only that some of them are halal (lawful and permissible) while others are haram (unlawful and impermissible).

Biological diversity (or Biodiversity), according to the Convention on Biological Diversity, refers to "the variability among living organisms from all sources including, inter alia, terrestrial, marine and other aquatic ecosystems and the ecological complexities of which they are part; this includes diversity within species, between species and of ecosystems"[1]. Central to biodiversity is the ecological complexity of interactions between biota and abiotic environment. All crops, livestock and marine animals and their interconnectivities of pollinators, symbionts, pests,

Manuscript received August 31, 2013; revised November 1, 2013.

A. K. H. Solihu is with Islamic Studies in the Department of General Studies, Faculty of Islamic Revealed Knowledge and Human Sciences, International Islamic University Malaysia, P. O. Box 10, 50728, Kuala Lumpur, Malaysia (e-mail: kabir70@yahoo.com). parasites, and predator-prey form part of biodiversity [2].

There are frequent references to several species in the Qur'an. Out of 114 surahs (chapters) of the Qur'an, six are titled after animals: Al-Baqarah (the Cow), al-An'am (the Cattles), al-Nahl (the Bee), al-Naml (the Ants), al-'Ankabut (the Spider), and al-Fil (the Elephant). But, as reported by Tlili [3], approximately thirty animal species are mentioned in various Qur'anic surahs. Only one surah bears a plant name, namely, al-Tin (the Fig), 95, but as Khafagi, Zakaria, Dewedar and El-Zahdany indicate, there are about 22 plants belonging to 17 families that are mentioned in the Qur'an [4].

This study explores the Qur'anic perspective of biological diversity in an attempt to elucidate the values assigned to nonhuman species in nature. The study first analyses key conceptual terms the Qur'an employs in reference to diversity in the biosphere and then identifies the status assigned to different components of biological diversity and ecological functions. The last part addresses the end value that could be drawn from the interdependence and coexistence of biotic and abiotic constituents of nature.

\section{COMPETING PARADIGMS}

Nature and several constituents of biodiversity have been valued differently based on different value systems. In the age of materialistic, economic driven world, financial implication of biodiversity is one of the predominant value methods. Nunes and van den Bergh provide four levels of biodiversity, each having its own value: genes, species, ecosystems and functions. Thereafter, they investigate the economic value and valuation method of each of these levels. They found that economic valuation could not measure the real but nonuse/passive values of biodiversity and will always fail to provide the entire range of biodiversity benefits [5].

From a more general framework, a Committee on Noneconomic and Economic Value of Biodiversity review different approaches to valuing biodiversity, such as economic, scientific, utilitarian, ethical, aesthetic. They discuss a variety of values that people derive from biodiversity and how such values have varyingly contributed to the advancement in science and technology as well as to the well-being of individuals and society. Yet they admit that no simple models or approaches can adequately address both market and nonmarket values due to our insufficient knowledge of interconnectivity of the components of biodiversity and the absence of detailed experimental studies of the ecosystem [6].

Ehrenfeld questions the very process of valuing biodiversity. According to him, value is an intrinsic part of biodiversity. Its value does not depend on anthropocentric benefits, be it economic, utilitarian, aesthetic, or even 
ecosystem services that human derive from it. Biodiversity is already valuable because it is there long before humans realized it. Since we do not know enough about the genes, species and ecosystem of biodiversity, our valuations will always remain wanting [7].

On the other side of biodiversity valuation stands a group of researchers who hold that biodiversity could endanger human health. It is argued that some species might be vectors of diseases to human population, contributing to the outbreak or spread of diseases. Maier challenges basing the value of the natural world on biodiversity, deconstructing arguments advanced by philosophers and scientists in favor of biodiversity and its conservation. He claims to appreciate natural value but outside the prism of biodiversity. Nature is valuable; biodiversity is not necessarily so. Thus, he framed nature's value on what he called "appropriate fit" which associates the core of natural value with a valuing relationship that people develop towards the natural world [8]. It is a particular human-nature relationship which human communities have devolved over their interaction with nature. How one could value the whole system while decrying its component parts is a question which Maier does not convincingly address in the book. This line of reasoning could be seen as part of mental and cultural alliance against nature's design and its intrinsic value which Bertrand Russell has earlier advanced in Why I am not a Christian. Russell acknowledges that humans are part of nature as far as their origin is concerned. But in the world of value, humans are the ultimate and irrefutable arbiters of values. As humans, he says, "we are the kings, and we debase our kingship if we bow down to Nature. It is for us to determine the good life, not for nature - not even for Nature personified as God" [9].

Very few biologists would subscribe to this purely humanistic line of reasoning and frame of valuation. In the Islamic worldview, there is strong support for the idea that biodiversity is intrinsically valuable and that it plays a pivotal role in maintaining ecosystem which is crucial to human life. This study analyses the value that the Qur'an assigns to biological diversity.

\section{KEY CONCEPTS}

Nature is presented in the Qur'an as "khalq Allah" (the creation of Allah) (Qur'an, 31:11) and "sun 'Allah" (the artistry of Allah) (Qur'an, 27:88). It is a huge garden in which the artifact of the caring but invisible gardener is ever present. The word "nature" is translated into Arabic as tabi 'ah. Tabi 'ah is not used in the Qur'an but its verbal forms of taba' $a$ and yatba ' $u$ are used to mean "to veil or seal" [10]. Taba ' $a$ and yatba ' $u$ are used exclusively with the word qalb (heart) to mean "to seal up heart", a meaning which has little to do with what tabi 'ah later came to be known for. Similarly, what is now known as al-tanawwu' al-bayuluji, a literal Arabic translation of "biological diversity", has no derivative in the Qur'anic vocabulary. Nevertheless, there are other phrases which give more or less a similar meaning. Mukhtalif and ikhtilaf are used in reference to diversity in nature and culture, both of which are derived from a verb ikhtalafa, which means "to differ". Mukhtalif is used when mentioning a number of biological items, such as animals and plants
(Qur'an, 6:141; 16:13; 35:27-28; 39:21), in that they are "diverse" or "different" in kind, color, and taste, while ikhtilaf is used more frequently in reference to the alteration of night and day (Qur'an, 2:164; 3:190; 10:6; 23:80; 45:5) and the diversity of human languages and skin colors (Qur'an, 30:22).

When mukhtalif is associated with some key similar words, such as alwan and dhara' $a$, it could well give a sense of biological diversity. Dhara'a, from which dhurriyyah (progeny) is derived means to "create and multiply" [10], [11]. Hence, yadhra'ukum as mentioned in surat al-Shura (Qur'an, 42:11) is translated as "He multiplies you" [12]. According to al-Sha'rawi, dhara'a signifies a creation with an innate capacity for self-replication and diversification [13]. The next keyword is alwan, a plural form of lawn. Lawn could mean "color" as well as "kind" ( $\operatorname{sinf}$ ) or both [11], depending on the context in which the word is used.

In surat al-Nahl, these three words are used in a single ayah (plural: ayat, meaning, the smallest unit of the surah of the Qur'an, commonly translated into English as "verse"). The Qur'an states: "wa-ma dhara'a la-kum fi al-ard mukhtalifan alwanuhu" which could be translated as "And what $\mathrm{He}$ has created and multiplied for you on earth of different species or of biological diversities." Here the phrase "fi al-ard mukhtalifan alwanuhu" could simply mean "biological diversity" or any kind of "earthly diversity". This is more so when the phrase is preceded with dhara'a (multiply). In his commentary on verse 16:13, Ibn 'Atiyyah (d. 542/1147) mentioned that lawn means color and type, but prioritized the second sense on the ground that the context is on the enumeration of God's bounties in nature, and that the benefits that could be obtained from these natural bounties are much greater when alwan is seen as species than when it is construed as colors [11].

Mukhtalif is used in association with alwan in different context to indicate the diversity of color and also used elsewhere in association with $u k u l$ to mean diversity in taste or flavor of earthly materials. For example, ayah 35:27 in the Qur'an says that God brings out crops (zar) of different colors, and another ayah (Qur'an, 6:141) says that God brings out crops of different tastes. The difference in color plus the difference in taste will inevitably amount to the difference in kinds and species.

\section{Differences in color + differences in taste $=$ differences in $\mathrm{kind} / \mathrm{species}$.}

Hence, in his translation of ayat 6:141, Yusuf 'Ali, bypassing this equation, deliberately or otherwise, simply renders it as "and tilth with produce of all kinds" [12] even though the literal translation should have been "and tilth with produce of different or diverse tastes". Perhaps each of color or taste is sufficient to grant a crop its distinct species.

Like dhara'a, baththa/yabuththu, as used in reference to biological items in the Qur'an, means "to spread," "to disperse" or "to scatter." The words suggest large, but indefinite, number of items being dispersed. The Qur'an states that nonhuman animals (dabbah) are spread on earth (Qur'an, 2:164; 45:4; 31:10). Baththa is also used to refer to the multiplication of humans through procreation (Qur'an, $4: 1)$. 
Additionally, there are several styles of expressions that list a variety of edible earthly materials. In the early part of surah al-Ra'd, the Qur'an states: "And in the earth are tracts (diverse though) neighboring, and gardens of vines and fields sown with corn, and palm trees - growing out of single roots or otherwise: watered with the same water, yet some of them We make more excellent than others to eat. Behold, verily in these things there are signs for those who understand!" (Qur'an, 13:4; see also 6:99). Such expressions suggest diversity within and across different items mentioned. Other words that address diversity in biological items include zawj (pair) and umam (communities), as will be discussed in the next section.

\section{COMMUnities WORTHY OF EXISTENCE}

A significant recognition of nonhuman species came in the context of Prophet Nuh (Noah), the most prominent prophet mentioned in the Qur'an after Prophet Adam in order of time. Prophet Nuh had preached to his people for a period of not less than 9,500 years, and much to his dismay the more he called them the farther they obstinately moved away from the path he was inviting them to (Qur'an, 29:14; 71:5-6). These people were thus due for all inclusive chastisement.

However, such chastisement may inadvertently affect other species of animals and plants and which may possibly lead to their extinction. In order to avoid this possible repercussion, Prophet Nuh was asked to take on board a minimum number of living beings (pair) necessary for reproduction and as many species as the ship can accommodate or those species within his reach, of course along with the few believing human beings. The Qur'an puts it as follows: "Ihmil fiha min kullin zawjayn ithnayn" (Qur'an, 11:40) and again elsewhere "fa-sluk fiha min kullin zawjayn ithnanyn” (Qur'an, 23:27). T. B. Irving translates the first ayah as: "Load her up with two apiece from every species" [14] and Yusuf "Ali renders the second ayah as "take thou on board pairs of every species, male and female" [12]

The keyword here is "zaw", a complex word having generally two broad senses. In its first, and more widely used, sense, it refers to a pair of male and female. The word could refer to either husband or wife separately, since each of husband and wife is named so when the other is borne in mind; husband is zawj and so is wife. In this case, the dual-plural form is zawjan, referring to both husband and wife. Zawj could also refer to both husband and wife collectively, having no need for further dual-plural form unless one wants to refer to four individuals [10], [15].

In the second sense, zawj refers to pair of any kind - of the same kind or even opposing kinds - outside the gender divide. Here zawj is identical with lawn and sinf both of which mean "kind". Muslim exegetes, such as al-Tabari (d. 310/923) [15], and lexicologists, such as Ibn Manzur (d. 711/1311) [10], recognize this second use as well. Al-Tabari reported from al-Hasan when explaining the meaning of ayah 11:40, as saying that each of the heaven and earth, the winter and summer, and the nighttime and daytime is zawj [15]. In short zawj will mean either male-female pair or any kind of breeding pair, necessary for reproduction. The purpose is to conserve different species from the pending catastrophe of the Great Flood.

Fakhr al-Din al-Razi (d. 606/1210) observes that the ayah requires Prophet Nuh to bring on board three types of being: 1) nonhuman animals, 2) Prophet Nuh's family, and 3) the believers. He then asks: "why is it that nonhuman animals were mentioned first and humans were mentioned last while the latter is the most honorable of all living beings? To this, he answered that human is endowed with reason by virtue of which he could comparatively find his way to safety and thus his safety is not the most urgent thing; rather the survival of animals in that circumstance is more necessary [16].

There are reports attributed to Ibn 'Abbas on how different species managed to coexist without predation. Of particular interest is the report that people started to complain their excessive wastes in the Ark and the annoyance of mouse. Prophet Nuh was then asked by God to rub the camel's tail and lion's face whence evolved a pair of pig and a pair of cat respectively. Pig fed on wastes and cat contained the spread of mouse [11]. Ibn 'Atiyyah quoted al-Qadi Abu Muhammad as saying that "these reports cannot be authenticated without evidence. Only God knows how things played out in the Ark" [11]. Whatever might be the case about the authenticity of the report, it does suggest a sense of ecological balance in which every living being, however repugnant or trivial it might seem to be, has an important role to play for the smooth operation of the whole system.

Other than this historical narrative, the Qur'an assigns to nonhuman species a communal word termed "umam", a plural form of ummah, meaning "communities", comparable to that of human communities. This is done in two places: the first one is mentioned in surat al-An'am 6:38 and the second one is mentioned in surat Hud 11:48. In the first place, the Qur'an states: "There is not an animal (that lives) on the earth, nor a being that flies on its two wings, but (forms part of) communities like you." (Qur'an, 6:38). It is not that all nonhuman animals are collectively umam but each species is ummah [16]. While the ayah does not specify in this context the exact commonalities between human ummah and nonhuman umam, there are other ayat that ascribe to nonhumans several communal characteristics:

First, nonhuman animals are comparable to humans in the sense that their sustenance, like that of humans, is provided by Allah as reported in the Qur'an: "There is no moving creature on earth but its sustenance dependeth on Allah" (Qur'an, 11:6); "How many are the creatures that carry not their own sustenance (rizqaha)? It is Allah who feeds (both) them and you: for He hears and knows (all things) (Qur'an, 29:60). In his commentary on this verse, Fakhr al-Din al-Razi explains that the genera and species of nonhuman animals are many. There are land species, marine species and mountain species, the exact number of which is known to Allah alone. It is He, the Almighty, who knows their natures, anatomies, and characteristics; their foods and poisons; their habitats; and what is congenial or uncongenial to their natures. To indicate how God's provision can reach all living beings, however infinitesimal a living organism might be, al-Razi quoted a report that says that when Prophet Musa began to worry about his family, God asked him to strike the rock with his staff. When he did, the rock split from which a second 
rock popped up; he struck again and a third rock popped up. He struck the rock for the third time then came out a small worm with something clinging to its mouth like its food, saying (and Musa was enabled to understand): "Glory be to Him Who sees me, hears my speech, knows my place and remembers me and not forgets me" [16]. Thus, animals are equally recipients of God's provisions.

Second, nonhuman animals are created and equally guided by God (Qur'an, 20:50). They coordinate among themselves for common good. A she-ant, a commander-in-chief, alerted others in its community to enter their dwellings lest Solomon and his hosts inadvertently crush them (Qur'an, 27:18). They also receive wahy (inspiration) from their God, Allah (SWT) and are guided to their habitats in search of shelters and provisions (Qur'an, 16:68-69). Bee is inspired to eat from a variety of fruit nectars and in turn produce honey which is of great use for humans (Qur'an, 16:68-69).

Thirdly, they worship God. Several Qur'anic verses indicate that nonhuman species perform 'ibadah (worship) as will be discussed later. In addition to these characters that could be drawn from the Qur'an itself, some Muslim exegetes narrated from Sufyan ibn 'Uyaynah (d. 198/815) that there are resemblances between human behaviors and animal behaviors. "Some would strike like lion; some would hunt like wolf; some would bark like dog; some would adorn himself like peacock; and some would behave like pig which when you give it a good food it would leave it but once you passed feces, it will devour it. In like manner, we can find among human beings who will not keep a single word from 50 words of wisdom he hears from you, but will capitalize on your one mistake and spread it all around" [16]. Hence different people mimic different animal behaviors. This perspective, however, could, hardly be grounded in the Qur'an.

The second place where "umam" is used to refer to nonhuman species is related to Prophet Nuh and his entourage upon their safe arrival, "O Noah! Come down (from the Ark) with peace from Us, and barakat ("blessing") on you and on umam from those with you (Qur'an, 11:48). Umam is a plural form of ummah, meaning "communities", but according to many Muslim exegetes, there were no other human communities with Prophet Nuh except those believers who joined him on the Ark who were actually few. This plural form in a place where singular form is expected has generated different interpretations of its implications. Many early Muslim exegetes of the Qur'an provided three possibilities. First, it has been suggested that umam (communities) refers to the same few believers with Prophet Nuh in the sense that they were groups; in this case, groups are regarded as communities. Second, umam refers to the descendants of those who were with Prophet Nuh. Third, it refers to the succeeding communities and generations among the believers until the end of the world. However, some contemporary Muslim exegetes of the Qur'an, such as Rashid Rida and al-Sha'rawi, added a fourth possibility that umam could as well refer to different species among nonhuman animals brought on board on the Ark, particularly when the Qur'an had already accorded them with the status of umam elsewhere (Qur'an, 6:38) [13].

It is important to understand the two welcoming expressions in the light of the keywords used, namely "salam" and "barakat" and the probable context and the circumstances of the passengers in the immediate aftermath of the Flood and disembarkation of the entourage. Less complicated, salam simply means peace. Barakat (a plural form of barakah), however, is commonly but inaccurately translated into English as "blessings". All of the 46 English translations of the Qur'an, surveyed by this author, render barakat in this verse as "blessings" [14]. However, there are significant semantic differences between both terms. In Webster Dictionary, "bless" is defined as: to consecrate or hallow by religious rite or word; to make the sign of the cross upon or over; to invoke divine care for; to praise; to make happy; to guard, protect, keep, preserve; and to favor, endow [17]. By contrast, barakah, as defined in Arabic lexicons, signifies three general meanings: 1) nama' wa-ziyadah (growth and increase); 2) Sa 'adah (happiness); and 3) quds (holy) [10], [18]. Blessing may incorporate the last two meanings of barakah, but not the first meaning, which is actually the basic meaning of the word. Even in religious use of the term, barakah signifies growth. Prophet Muhammad used to wish a newly married person with barakah in his saying "baraka Allahu laka, wa-baraka 'alayka wa-jama" baynakuma fi-khayr" [19] (May Allah give you barakah, may He shower you with barakah, and may He bring you together in goodness). The prayer is to wish blessed increase and growth for the couple through procreation.

The meanings of the two words and the circumstances on the ground would give credibility to the inclusion of nonhuman species in the disembarking umam. It should be noted that these nonhuman species had to vacate their habitats possibly to escape extinction. They were on the same life boat with human passengers and they had to suffer the same pain of long voyage as humans did. So they were not less in need of God's barakah than humans. In the first place, they needed "peace", some sort of "contract" or "truce" to avoid perdition-pray at least in the immediate aftermath of arrival; otherwise the whole purpose of bringing the prey animals to safety will not be fulfilled. They also need rapid growth in their respective populations. Thus God's peace and barakat were extended to them as well.

\section{Sign In DESIGN}

The Qur'an regards the natural world as an open field where God's ayah is constantly and irresistibly displayed to all nature's inhabitants. Etymologically, ayah means "signs". It is used in the Qur'an to refer to the smallest unit of the surah of the Qur'an or simply "verse" (Qur'an, 10:1; 11:1; $12: 1 ; 13: 1)$ as stated above; it is also used to refer to Allah's creatures in nature and actions in human history (Qur'an, $3: 190 ; 11: 103)$.

Before explaining how nature's design is seen as ayah, it is pertinent to recount some of nature's provisions. Plant and animal are essential provisions for humankind. Plant is the animal's primary source of food, providing the basic human needs in terms of food, shelter, medicine and acting as an essential ingredient of biosphere and ecology. Estimates of plant species range from 250,000 to over 400,000 [2]. Yet, it is believed that around $95 \%$ of our food come from only 20 
species of plants, and $80 \%$ of which come from six of those species [4]. Furthermore, species of plants and animals have long been beneficial in pharmaceutical products and healthcare systems. According to the World Health Organization, an estimated $80 \%$ of people in developing countries obtain their primary health care needs in the form of traditional medicines about $85 \%$ of which are derived from plant extracts [20]. Cohen and Tilman concluded that "no one yet knows how to engineer systems that provide humans with the life-supporting services that natural ecosystems produce for free" [6].

Different services provided by different beings in nature (of the animal world, vegetable world and minerals,) are cited across several surahs of the Qur'an as part of God's benevolence upon humankind. At least in two occasions, two species of plants are reported to be sources of comfort to two prominent figures of the Qur'an. First, Prophet Yunus (Jonah), having being swallowed by fish and later regurgitated on the desert shore, became feeble and sick. Thereupon, a tree was caused to grow to provide him shelter and comfort (Qur'an, 37:145-146). Similarly, when Maryam (Mary), the Mother of Prophet Isa (Jesus), cried out in pain of childbirth: "Ah! would that I had died before this, and had become a thing forgotten, utterly forgotten!," she was comforted with a running rivulet and a palm-tree from which she could drink water and eat fresh ripe dates (Qur'an, 19:23-26). The benefits that human derive from plants and animals, as reflected in the Qur'an, could be summarized in the following long passage of the Qur'an:

And cattle He has created: from them you derive warmth, and numerous benefits, and of their (meat) you eat... It is He who sends down water from the sky: from it you drink, and out of it (grows) the vegetation on which you feed your cattle. With it He produces for you corn, olives, date-palms, grapes and every kind of fruit: verily in this is a sign for those who reflect... And whatsoever He has created (and multiplied) for you on earth of varying kinds (and colors): surely in that is a sign for people who reflect and are mindful... Is then $\mathrm{He}$ Who creates like one that creates not? Will you not reflect and be mindful? If you would count up the favours of Allah, never would you be able to number them: for Allah is Oft-Forgiving, Most Merciful (Qur'an, 16:5-18).

While one may look at all this as the natural course of action which cannot be thought of otherwise, the Qur'an considers the very constant functioning of the natural phenomena and the ecological services provided therein as God's signs in nature in the sense that God designed the system in a delicate balance and made it interactive. The pollination and honey-making of bee, the sailing of ship on sea, the flight of birds on its wings and many more are seen as part of God's signs in design. As enumerated in a passage in surat al-Waqi'ah (56:63-73), the Qur'an says: "Have you ever considered the seed which you cast upon the soil? Is it you who cause it to grow - or are We the cause of its growth? Again, "Have you ever considered the water which you drink? Is it you who cause it to come down from the clouds or are we the cause of its coming down?" Still, "Have you ever considered the fire which you kindle? Is it you who grow the tree which feeds the fire, or do we grow it?" These amenities and services, as noted in the concluding ayah, are all "tadhkirah" (a memorial of God's handiwork), and "mata" (a boon or an article of comfort) for their beneficiaries and the denizens (see also 80:24-32). The fact that each of nature's constituents renders its assigned bounty whenever its conditions are met indicates that there is a divinely designed functioning system in place. Yet the Qur'an reminds us that these services could be terminated if God so wishes. Water which occupies major part of the earth and is the source of all life [21], could have dried up if God so wishes (Qur'an, 23:18; 67:30). Similarly, crops could have been reduced to rubble if God so wills (Qur'an, 56:65).

The manifestation of ayat is not confined to biological resources, but is extended to the whole cosmos. For example, the Qur'an makes reference to birds on various occasions. Of all nonhuman animals mentioned in the Qur'an, it is bird as well as camel, that the Qur'an draws attention to in terms of their creation and design (Qur'an, 16:79; 67:19; 88:17); and the bird alone was mentioned in the Qur'an to exist in Paradise (Qur'an, 56:21) the kind of which, however, is known to God alone. In reference to the flight of birds, the Qur'an states: "Have they not seen the birds, held poised in the midst of (the air and) the sky? Nothing holds them up but (the power of) Allah. Verily in this are signs for those who believe" (Qur'an, 16:79; see also 67:19).

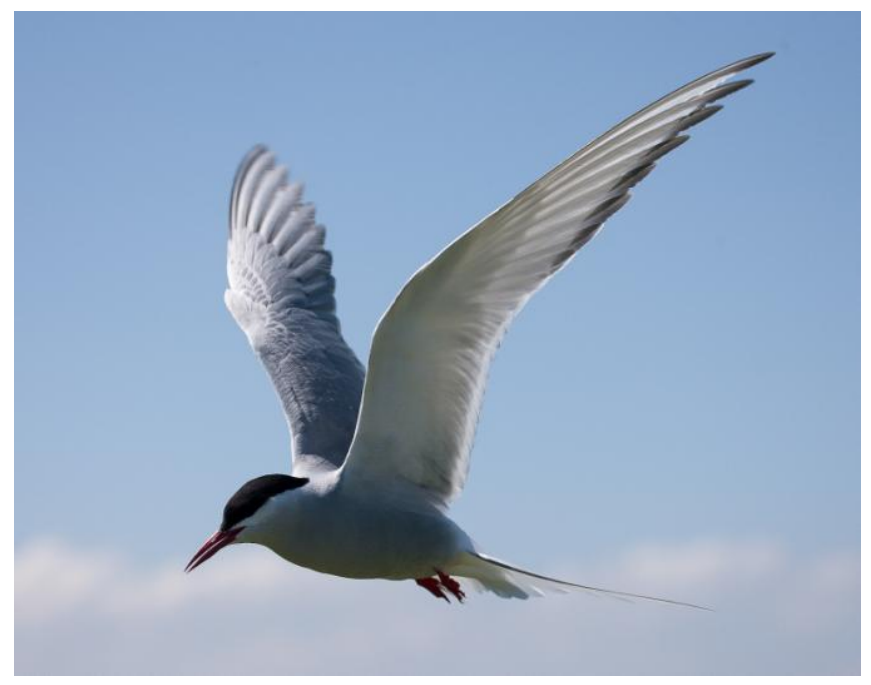

Fig. 1. Arctic Tern, by Andy Mason retrieved from http://btomigrationblog.blogspot.com/2012_04_01_archive.html.

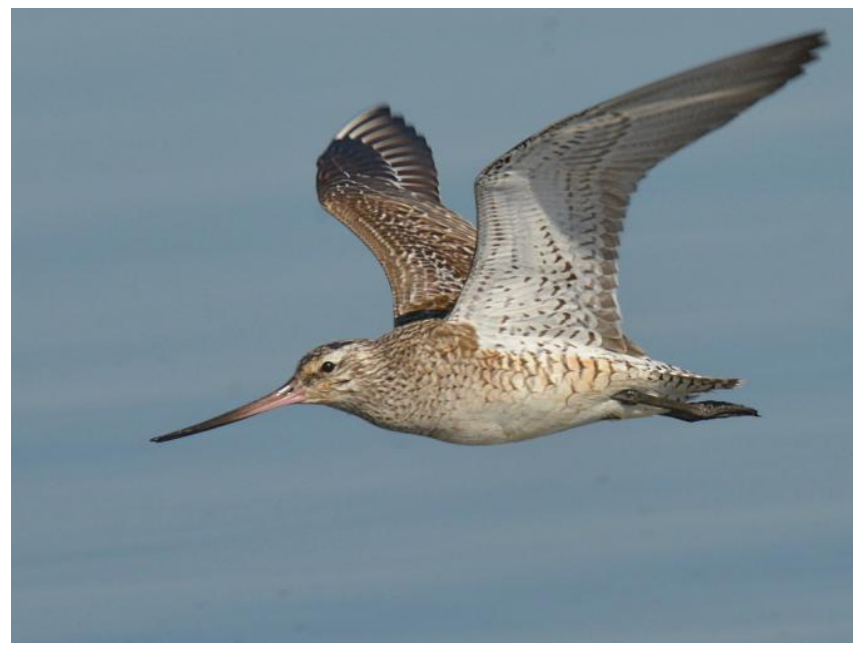

Fig. 2. Bar-tailed Godwit retrieved from: http://www.flickr.com/photos/jvverde/8843318065/. 
It is noteworthy that recent research has indicated that of all known migrant species, birds, tracked through satellite transmitters, travel the farthest. Arctic Tern migrates over $24,000 \mathrm{~km}$ within 40 days (with some pause) or more than $80,000 \mathrm{~km}$ annually (Fig. 1) [22]. Bar-tailed Godwit's migration is the longest known non-stop flight for any bird and also the longest journey without pausing to feed by any animal, covering more than $11,000 \mathrm{~km}$ within 9 days [23] (Fig. 2). "Can we expect the bar-tailed godwit record of a $11,000-\mathrm{km}$ non-stop flight to be broken?" is a question which Hedenström answered negatively on the grounds that "the physical limitations of the Earth do not offer any combination of ecologically feasible breeding and wintering areas more distantly apart that would require longer flights" [24]. Whether Hedenström's prediction will hold and whether or not nature stores more of this type in its archive which we are yet to uncover or explore, only time will tell.

Several ayat refer to birds for different meanings. Inspired by God, a bird called Ghurab (crow) taught human what could be the first biomimicry, how to bury dead body (Qur'an, 5:31). Four birds of different species [16] were killed and then brought back to life to illustrate the possibility of Resurrection in the Hereafter (Qur'an, 2:260). Birds formed part of Prophet Sulayman's army one of which named Hudhud (Hoopoe) introduced Prophet Sulayman to Queen Bilqis and her people in Saba' (Sheba) (Qur'an, 27:20-28). Flocks of birds were deployed to chastise the ashab al-fil (the Army of the Elephant) (Qur'an, 105:1-5). Bird was cited as part of Prophet Isa's miracle (Qur'an, 3:49; $5: 110)$ and associated with the dream of Prophet Yusuf's inmate (Qur'an, 12:36, 41). Like human and other nonhuman species, birds form their own communities (Qur'an, 6:38) and celebrate God's praises among themselves (Qur'an, 24:41) and along with Prophet Dawud (David) (Qur'an, 21:79).

Biological and non-biological objects seen as ayat are compiled in the early part of surah al-Jathiyah. The creation of the heaven and earth is ayah; the creation of human beings and nonhuman animals is ayah; and the alternation of night and day as well as water sent to revitalize the earth and the change of the winds are also ayah (Qur'an, 45:6). These ayat of the natural phenomena are summed up with the following: "These are the ayat (signs) of Allah that We recite to you in truth. In what other statement, if not in God and His ayat, will they, then, believe? (Qur'an, 45:6). It is remarkable to observe that the Qur'an uses the word "natlu" (from tilawah or recitation) to refer to the recitation of the preceding ayat in nature in a similar way it refers to the recitation of ayat of the Qur'an itself (Qur'an, 18:27; 29:45; 35:29; 73:4). God is the Author of the Qur'an and the Creator of nature. Thus each part or verse of the Qur'an and each component or constituent of nature is a sign, pointing to and bearing the hallmark of its author-cum-creator. The value of the preservation of the signs of Allah for successive generations, as Khan Chishti observes, outweighs the transient and often conflicting economic benefits that obliterate or obscure the presence of these signs [25].

\section{UNITY IN DIVERSITY}

What types of existential value that could be drawn from this biological diversity? At least in the Qur'an, biological diversity is presented to be purposeful, made by design not by accident. Plant is supported by minerals; animal is supported by both minerals and plants and human is supported by all of them. Diversity of species with exceedingly complementary needs ensures a waste free world in which the waste of one is the food of the other. This intricate web of coexistence and interdependence, according to the Qur'an, ultimately points to a common origin and shared values.

It should be noted that the phenomenon of diversity at different levels as presented in the Qur'an is universal. There is human cultural diversity, in that humans are diverse in language and skin color as well as in their cultures and tribes (Qur'an, 30:22; 49:13). There are narratives of different communities and cultures and how they were meant to vie for excellence in khayrat (good deeds) (Qur'an, 2:148; 5:48). Yet in the final analysis, they were traced back to a single soul (nafs wahidah) along with its pair (Qur'an, 4:1; 6:98; $7: 189 ; 39: 6)$. There are also highlights of nonhuman animals and plants of extremely diverse colors, shapes and tastes. Yet they, along with humans, are reduced to water (Qur'an, $21: 30 ; 24: 45 ; 25: 54)$. Similarly, there are inanimate things the Qur'an refers to, such as the sun, the moon, stars, mountains, seas, rivers, wind, and so on. Yet they along with all animate living beings are ultimately reduced to a single divine command of "kun fa-yakun" ("Be," and it is) (Qur'an, $2: 117 ; 16: 40 ; 36: 82 ; 40: 68)$. This ultimate unity in diversity is the cosmic value embodied in tawhid (unity of God) as manifested in the biosphere (Fig. 3). Had there been other gods beside Allah, this cosmic contract of coexistence and interdependence would have disintegrated, leading to all-out war of all against all (Qur'an, 21:22; 23:91). Functioning as what could be termed as a Central Uniting Process (CUP), tawhid is at the pinnacle of the Qur'anic value of biodiversity. The unity of creation is presented in the Qur'an as the grand indicator of the unity of the Creator.

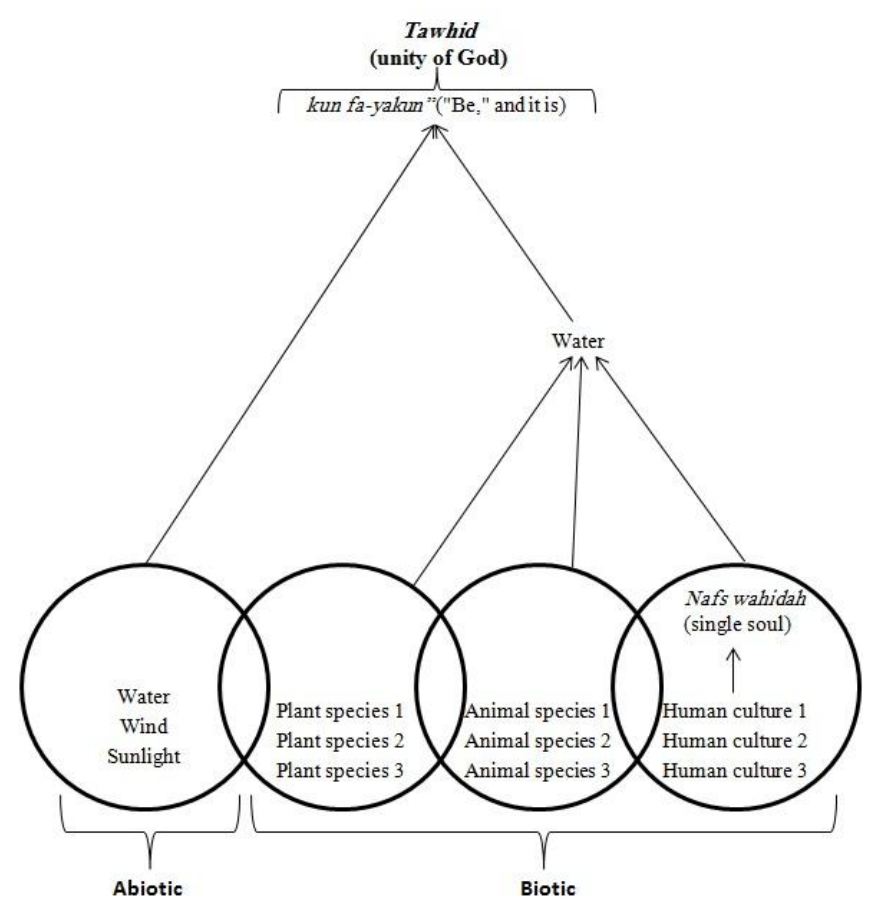

Fig. 3. Unity of existence as exemplified in biosphere in realization of cosmic value. 
Furthermore, several Qur'anic verses indicate that nonhuman species perform salah (prayer), tasbih (glorification), sujud (prostration), in manners and languages that are not comprehensible to humans. In fact, the whole cosmos in its diversified taxonomy - animate, inanimate, organic and inorganic, biotic and abiotic, terrestrial and celestial etc. - are reported to be in constant worship to God. Only humans out of their freewill may choose or choose not to worship God (Qur'an, 16:48-49; 17:44; 22:18).

\section{CONCLUSION}

The Qur'an regards nonhuman species as communities of worshippers worthy of existence and conservation. They are valuable in themselves and provide aesthetic values and ecological services necessary for human well-being. As discussed in this study, biological diversity is not accidental but purposeful, seen in the Qur'an as a prime indicator of the existence and unity of God. A world without animals drumming, birds singing and dancing, and plants watching, all through the courtesy of minerals - in a grand show of a divinely designed functioning system - would be too lonely, too unbearable for humans to live in. In this intricate web of coexistence and interdependence, we must learn to live and let live.

\section{REFERENCES}

[1] L. L. Mai, M. Y. Owl, and M. P. Kersting, "Biological Diversity," The Cambridge Dictionary of Human Biology and Evolution, Cambridge: Cambridge University Press, 2005.

[2] M. E. Dulloo, "Global Challenges for Agricultural Plant Biodiversity and International Collaboration," in Conservation of Tropical Plant Species, M. N. Normah, H. F. Chin, \& B. M. Reed, Eds. New York: Springer, 2012, chap 19, pp. 491-509.

[3] S. Tlili, Animals in the Qur'an, Cambridge: Cambridge University Press, 2012.

[4] I. Khafagi, A. Zakaria, A. Dewedar, and K. El-Zahdany, "A Voyage in the World of Plants as Mentioned in the Holy Quran," International Journal of Botany, vol. 2, no. 3, pp. 242-251, 2006.

[5] P. A. L. D Nunes and J. C. J. M. van den Bergh, "Economic valuation of biodiversity: sense or nonsense?" Ecological Economics, vol. 39, no. 2, pp. 203-222, November 2001.

[6] Committee on Noneconomic and Economic Value of Biodiversity, Perspectives on Biodiversity: Valuing Its Role in an Everchanging World, Washington, D.C.: National Academy Press, 2003.

[7] D. Ehrenfeld, "Why Put Value on Biodiversity," in Biodiversity, E. O. Wilson, F. M. Peter Eds. Washington, D.C.: National Academic Press, 1988 , ch. 24 , pp. 212-216.
[8] D. S. Maier, What's So Good about Biodiversity: A Call for Better Reasoning About Nature's Value, Dordrecht, Netherlands, Springer, 2012.

[9] B. Russell, What I Believe, Abingdon, Oxon: Routledge, 2013.

[10] M. Ibn Manzur, The Arab Tongue (Lisan al- 'Arab), Beirut: Dar Sadir, 2011.

[11] A. Ibn 'Atiyyah, Tafsir Ibn 'Atiyyah (Al-Muharrir al-Wajiz fi Tafsir al-Kitab al-'Aziz), Beirut: Dar al-Kutub al-'Ilmiyyah, 2007.

[12] A. Yusuf 'Ali, "The Meaning of the Holy Qur'an: Text and Translation," Kuala Lumpur: Islamic Book Trust 2007, Maryland: Amana Publication, 2006.

[13] M. Al-Sha'rawi, Tafsir al-Sha rawi, Cairo: Akhbar al-Yawm, 1991.

[14] Islam Awakened. (July 20, 2013). Comparative translations of the Qur'an [Online]. Available: http://www.islamawakened.com/quran/11/48/default.htm.

[15] I. Al-Tabari, "Jami 'al-Bayan 'an Ta'wil Ay al-Qur'an," Tafsir al-Tabari, Cairo: Dar al-Hadith, 2010.

[16] F. Al-Razi, Tafsir al-Fakhr al-Razi, Beirut: Dar Al-Fikr, 2005.

[17] Webster's Third New International Dictionary of the English Language, P. B. Gove, Ed. Springfield, Massachusetts: Merriam-Webster, 1993.

[18] E. W. Lane and S. Lane-Poole, An Arabic English Lexicon, New York: Cosimo, Incorporated, 2011.

[19] S. Abu Dawud, Sunan Abi Dawud, Riyadh: Dar al-Salam, 2009, hadith no. 2130.

[20] World Health Organization. (2013, September 30). Traditional Medicine 2008 [Online]. Available: http://www.who.int/mediacentre/factsheets/fs134/en/.

[21] M. J. Ingrouille and B. Eddie, Plants: Evolution and Diversity, Cambridge: Cambridge University Press, 2006.

[22] C. Egevang, I. J. Stenhouse, R. A. Phillips, A. Petersen, J. W. Fox, and J. R. D. Silk, "Tracking of arctic terns sterna paradisaea reveals longest animal migration," in Proc. the National Academy of Sciences of the United States of America, February 2010, vol. 107, no. 5, pp. 2078-2081.

[23] R. E. Gill, T. L. Tibbitts, D. C. Douglas, C. M. Handel, D. M. Mulcahy, J. C. Gottschalck, N. Warnock, B. J. McCaffery, P. F. Battley, and T. Piersma, "Extreme endurance flights by landbirds crossing the Pacific Ocean: ecological corridor rather than barrier?," in Proc. the Royal Society B, February 2009, vol. 276, no. 1656, pp. 447-457.

[24] A. Hedenström, "Extreme endurance migration: what is the limit to non-stop flight?" PLoS Biol, vol. 8, no. 5, May 2010.

[25] S. K. K. Chishti, "Fițrah: An Islamic Model for Humans and the Environment," in Islam and Ecology: A Bestowed Trust, R. C. Foltz, F. M. Denny, and A. Baharuddin, Eds. Cambridge, Mass.: Center for the Study of World Religions, Harvard Divinity School, 2003, pp. 67-82.

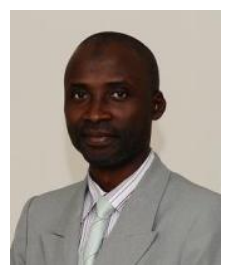

A. K. H. Solihu is an associate professor of Islamic Studies in the Department of General Studies, Faculty of Islamic Revealed Knowledge and Human Sciences, International Islamic University Malaysia, P. O. Box 10, 50728, Kuala Lumpur, Malaysia. 